\title{
Positioning Regarding Type 2 Diabetes Reversibility under Unconventional Treatment. What about Genetic and Vitamin Status of Patients?
}

\author{
Belazzouz Abderrahmen Youssouf* \\ Internal Medicine Department, Sisters Bedj Hospital, Algeria
}

Submission: September 09, 2019; Published: November 19, 2019

*Corresponding author: Belazzouz Abderrahmen Youssouf, Internal Medicine Department, Sisters Bedj Hospital, City 42 log N37 Chettia Chlef, Algeria

\begin{abstract}
A great controversy has emerged recently regarding the effectiveness of unconventional therapies such as: bariatric surgery, intermittent fasting and their ability to cure type 2 diabetes versus the conventional approaches that accompany diabetic patient throughout his life with the need for a therapeutic escalation. Nevertheless, three facts are missing in this approach, the first is the little step back with it especially on the cardiovascular prognosis and the second is the application on pathology such as type 2 diabetes so heterogeneous that the therapeutic response can't be extrapolates. Finally, what is the frequency and severity of subsequent recurrences of diabetes? And will this approach still be as effective? Hence the interest of taking into account two essential aspects before starting this process, the genetic status that modulates the therapeutic response whether for the classical or contemporary approach and which will be necessary to establish a score in order to select the responders to this approach. And vitamin status especially since this new therapeutic method is based primarily on weight loss and all that goes with vitamin losses that may trigger a cascade of subclinical atherosclerosis maintained despite the reversibility of diabetes.
\end{abstract}

Keywords: Diabetes reversibility; Unconventional therapies; Bariatric surgery; Intermittent fasting

\section{Introduction}

The number of diabetic type 2 is increasing exponentially is going to be 642 milions in 2040 [1]. Who says an increase in the number says an excess of marketing anti diabetic drugs.

In everyday clinical practice, it is well known that type 2 diabetes responds differently to conventional treatment (oral anti diabetic drugs and insulin) [2]. This variable therapeutic response depends on several factors such as BMI, treatment adherence but above all a genetic determinant [3]. Recent studies have shown the reversibility of type 2 diabetes after some unconventional therapeutic procedures such as bariatric surgery and intermittent fasting [4], knowing that both procedures will lead to this cure through weight loss.

Nevertheless it was necessary to point out two important aspects which are the genetic and vitamin status of diabetics included in these studies. In fact, these approaches, with an imminent short-term exploit illustrated by type 2 diabetes reversibility, do not make it possible to exclude a stronger recurrence of his diabetes or the onset of subclinical atherosclerosis that will interact with time and worsen despite the reversibility of diabetes. In fact, in a similar way to the therapeutic response of conventional approaches, a variable response to the unconventional approach will be predictable, whether it be in the short term that will depend mainly on the genetic status but also on the BMI and the pancreatic beta cell pool. In the long term, it is necessary to take more precaution in this type of therapeutic approach which depends on the vitamin status.

Recently a new pathological entity has emerged is the infra clinical deficit vitamin B12 that is common in diabetics [5]. Clinically defined by the absence of hematologic or neurological signs, biochemically by a vitamin B12 (119-186) pmol / l; homocysteine (13.6-19.2) umol / l [6].

Hyperhomocysteine has recently emerged as a risk factor for macro angiopathy with diabetic cardiovascular complications. This deficiency has recently been linked to the conventional therapeutic approach of taking metformin and oral anti diabetic drugs [7]. Nevertheless, the unconventional approach also 
leads to vitamin deficits through weight loss. So even after diabetes cure, if the atherosclerosis process has been triggered maintenance does not necessarily require the persistence of hyperglycemia, moreover, studies have shown that pre diabetes and diabetes give both cardiovascular complications [8].

\section{Conclusion}

For all new therapies against diabetes, two conditions are required: safety on the cardiovascular system and efficacy. If this new approach (bariatric surgery and fasting) has been able to establish its effectiveness superior to the conventional approach. Cardiovascular prognosis remains a topic of debate, taking into account the vitamin and genetic status seems a necessity and studies on a large number of patients and longer follow-up should be required before extrapolating this practice which seems promising but uncertain cardiovascular prognosis.

\section{References}

1. International Diabetes Federation (2015) IDF Diabetes Atlas. ( $7^{\text {th }}$ edn).

2. Kleinberger JW, Pollin TI (2015) Personalized medicine in diabetes mellitus: current opportunities and future prospects. Ann N Y Acad Sci 1346(1): 45-56.
3. Dimas AS, Lagou V, Barker A (2014) MAGIC Investigators. Impact of type 2 diabetes susceptibility variants on quantitative glycemic traits reveals mechanistic heterogeneity. Diabetes 63(6): 2158-2171.

4. Furmli S, Elmasry R, Ramos M, Fung J (2018) Therapeutic use of intermittent fasting for people with type 2 diabetes as an alternative to insulin. BMJ Case Rep.

5. Belazzouz Abderahman Youssouf, Boudiba Aissa, Azzouz Malha (2018) Infra-Clinical Vitamin B12 Deficiency and Microangiopathic Profile, is this a New Risk Factor in Type 2 Diabetics? Algerian Experience. Int J Diabetes Metab Disord 3(1): 1-4.

6. Hannibal L, Lysne V, Bjørke-Monsen AL, Behringer S, Grünert SC, et al. (2016) Biomarkers and Algorithms for the Diagnosis of Vitamin B12 Deficiency. Front Mol Biosc 3: 1-27.

7. Ko SH, Ko SH, Ahn YB, Song KH, Han KD, et al. (2014) Association of Vitamin B12 Deficiency and Metformin Use in Patients with Type 2 Diabetes. J Korean Med Sci 29(7): 965-972.

8. Handelsman Y, Bloomgarden ZT, Grunberger G, Umpierrez G, Zimmerman RS, Bailey TS, et al. (2015) American Association of Clinical Endocrinologists and American College of Endocrinology: clinical practice guidelines for developing a diabetes mellitus comprehensive care plan--2015. Endocr Pract 21(Suppl 1): 1-87.

Your next submission with Juniper Publishers will reach you the below assets

- Quality Editorial service

- Swift Peer Review

- Reprints availability

- E-prints Service

- Manuscript Podcast for convenient understanding

- Global attainment for your research

- Manuscript accessibility in different formats

( Pdf, E-pub, Full Text, Audio)

- Unceasing customer service

Track the below URL for one-step submission

https://juniperpublishers.com/online-submission.php 